\title{
Pengaruh Pengalaman Auditor, Komitmen Organisasi, Kompetensi Auditor Dan Reward Pada Audit Judgment
}

\author{
Ni Made Krisdhayani ${ }^{1}$ \\ Ida Bagus Putra Astika ${ }^{2}$
}

${ }^{1}$ Fakultas Ekonomi dan Bisnis Universitas Udayana (Unud), Bali, Indonesia
email: krisdhayanidindaa @ gmail.com/ Telp: +6282236353344
${ }^{2}$ Fakultas Ekonomi dan Bisnis Universitas Udayana (Unud), Bali, Indonesia

\begin{abstract}
ABSTRAK
Tujuan penelitian ini adalah untuk mendapatkan bukti empiris pengaruh pengalaman auditor, komitmen organisasi, kompetensi auditor dan reward pada audit judgment di KAP Provinsi Bali. Penelitian ini dilakukan pada Kantor Akuntan Publik yang berada di Provinsi Bali. Populasi penelitian ini adalah seluruh auditor yang bekerja di Kantor Akuntan Publik di Bali tahun 2017 yang berjumlah 77 orang. Unit analisis penelitian ini adalah individu yaitu auditor yang bekerja pada 9 Kantor Akuntan Publik di Provinsi Bali. Teknik penentuan sampel yang digunakan dalam penelitian ini adalah teknik sampel jenuh atau sensus, yaitu teknik penentuan sampel dengan semua anggota populasi digunakan sebagai sampel. Teknik analisis data yang digunakan dalam penelitian ini adalah analisis regresi linier berganda. Hasil analisis menunjukkan bahwa pengalaman auditor berpengaruh positif pada audit judgment, komitmen organisasi berpengaruh positif pada audit judgment, kompetensi auditor berpengaruh positif pada audit judgment, dan reward berpengaruh positif pada audit judgment.
\end{abstract}

Kata kunci : pengalaman, komitmen, kompetensi, reward, audit judgment.

\begin{abstract}
The purpose of this study was to obtain empirical evidence of the influence of auditor experience, organizational commitment, auditor competence and reward on audit judgment in KAP Bali Province. This research was conducted at the Public Accountant Office in Bali Province. The population of this study is all auditors working in the Public Accountants Office in Bali in 2017, amounting to 77 people. The unit of analysis of this study is the individual who is the auditor who works in 9 Public Accounting Firms in Bali Province. The sample determination technique used in this study is saturated sample or census technique, which is the technique of determining samples with all members of the population used as samples. The data analysis technique used in this study is multiple linear regression analysis. The results of the analysis show that auditor experience has a positive effect on audit judgment, organizational commitment has a positive effect on audit judgment, auditor competence has a positive effect on audit judgment, and reward has a positive effect on audit judgment.

Keywords: experience, commitment, competence, reward, audit judgment.
\end{abstract}

\section{PENDAHULUAN}

Pesatnya perkembangan perusahaan yang telah go public diwajibkan untuk menyusun laporan keuangan selama satu periode akuntansi untuk menunjukkan kinerja keuangan perusahaan kepada pihak-pihak yang berkepentingan dalam pengambilan keputusan keuangan. Laporan keuangan menggambarkan kondisi 
Ni Made Krisdhayani dan Ida Bagus Putra Astika. Pengaruh...

hasil usaha dan keuangan suatu perusahaan. Laporan keuangan dijadikan sumber informasi keuangan yang sangat dibutuhkan untuk pengambilan keputusan dan juga sebagai indikator pengukuran kinerja suatu perusahaan.

Perusahaan melakukan pemeriksaan laporan keuangan oleh pihak ketiga yang independen. Mulyadi (2010) menjelaskan bahwa manajemen perusahaan atau suatu entitas memerlukan jasa pihak ketiga agar pertanggungjawaban keuangan yang disajikan kepada pihak luar dapat dipercaya, sedangkan pihak luar perusahaan memerlukan jasa pihak ketiga untuk memperoleh keyakinan bahwa laporan keuangan yang disajikan oleh manajemen perusahaan dapat dipercaya sebagai dasar keputusan yang diambil oleh mereka. Tanpa menggunakan jasa auditor independen, entitas perusahaan tidak dapat meyakinkan pihak di luar perusahaan bahwa keakuratan laporan keuangan yang telah disusun dan diberikan berisi informasi yang dapat dipercaya. Profesi jasa pihak ketiga ini merupakan profesi kepercayaan masyarakat. Namun, trerjadinya kasus kegagalan audit dalam beberapa dekade belakangan ini, telah menimbulkan krisis kepercayaan masyarakat mengenai ketidakmampuan profesi akuntansi dalam mengaudit laporan keuangan. Munculnya krisis ini memang beralasan, karena cukup banyak laporan keuangan suatu perusahaan yang mendapat opini wajar tanpa pengecualian, tetapi justru mengalami kebangkrutan setelah opini tersebut dikeluarkan (Idris, 2012).

Contoh kasus kegagalan audit yang mengindikasikan lemahnya audit judgement salah satunya seperti yang disampaikan Abdul Malik (2017) yaitu adanya kasus mitra kantor akuntan Ernest \& Young's yang melakukan gagal audit, karena 
terdapat temuan oleh PCAOB yang menyatakan EY melaporkan hasil audit yang tidak memadai mengenai perusahaan telekomunikasi (PT. Indosat Tbk) yang menyebabkan kantor mitra EY membayar denda atas kesalahan tersebut. Berita ini disampaikan dalam media TEMPO.CO, Washington yang menyatakan bahwa Kantor akuntan publik mitra Ernst \& Young's (EY) di Indonesia, yakni KAP Purwantoro, Suherman \& Surja sepakat membayar denda senilai US\$ 1 juta (sekitar Rp 13.3 miliar), akibat divonis gagal melakukan audit laporan keuangan kliennya. Kesepakatan diumumkan oleh Badan Pengawas Perusahaan Akuntan Publik AS (Public Company Accounting Oversight Board/PCAOB) pada Kamis, 9 Februari 2017, waktu Washington. Kasus itu merupakan insiden terbaru yang menimpa kantor akuntan publik, sehingga menimbulkan keprihatinan apakah kantor akuntan publik bisa menjalankan praktik profesinya di Negara berkembang sesuai kode etik. “Anggota jaringan EY di Indonesia yang mengumumkan hasil audit atas perusahaan telekomunikasi pada 2011 memberikan opini yang didasarkan atas bukti yang tidak memadai," demikian disampaikan pernyataan tertulis PCAOB, seperti dilansir Kantor Berita Reuters, dikutip Sabtu, 11 Februari 2017. Temuan itu berawal ketika kantor akuntan mitra EY di AS melakukan kajian atas hasil audit atas perusahaan telekomunikasi itu tidak didukung dengan data yang akurat, yakni dalam hal persewaan lebih dari 4000 unit tower selular. "Namun afiliasi EY di Indonesia itu merilis laporan hasil audit dengan status wajar tanpa pengecualian," demikian disampaikan PCAOB. PCAOB juga menyatakan tidak lama sebelum dilakukan pemeriksaan atas audit laporan pada 2011, afiliasi EY di Indonesia menciptakan belasan pekerjaan audit baru yang "tidak benar", sehingga menghambat proses pemeriksaan. PCAOB selain mengenakan denda US\$ 1 juta juga memberikan sanksi 
Ni Made Krisdhayani dan Ida Bagus Putra Astika. Pengaruh...

kepada kedua auditor mitra EY yang terlibat dalam audit pada 2011. "Dalam ketergesaan mereka atas untuk mengeluarkan laporan audit untuk kliennya, EY dan dua mitranya lalai dalam menjalankan tugas dn fungsinya untuk memperoleh bukti audit yang cukup", ujar Claudius B Modesti, Direktur PCAOB divisi penegakan dan Investigasi.

Kasus gagal audit menimbulkan dampak yang sangat merugikan di masa depan. Seperti halnya tuntutan hukum, hilangnya profesionalisme, hilangnya kepercayaan publik dan kredibilitas sosial. Untuk mencegah terjadinya kasus kegagalan audit, auditor dituntut untuk bersikap profesional. Sikap profesionalisme telah menjadi isu yang kritis untuk profesi akuntan karena dapat menggambarkan kinerja akuntan tersebut. Sikap profesionalisme auditor dapat dicerminkan oleh ketepatan auditor dalam membuat judgement dalam penugasan auditnya (Idris, 2012).

Salah satu tugas seorang auditor adalah melakukan proses audit untuk mencari keterangan tentang apa yang dilakukan dalam suatu entitas yang mampu memeriksa keakuratan laporan keunngan, membandingkan hasil audit dengan kriteria yang ditetapkan, serta menyetujui dan menolak hasil dengan memberikan rekomendasi tentang tindakan-tindakan perbaikan secara objektif. Ketika melakukan tugas sebagai seorang auditor, tidak semua auditor dapat melakukan tugasnya dengan baik dan masih ada beberapa akuntan publik yang melakukan kesalahan.

Seorang auditor yang jujur dalam melaksanakan tugasnya dan bekerja tanpa tekanan atas permintaan pihak tertentu pribadinya akan dapat mempertahankan 
integritas (Mayasari,2011). Agar seorang auditor dapat melaksanakan tugas tersebut dibutuhkan sebuah audit judgment dimana auditor mengumpulkan bukti dalam waktu yang berbeda dan mengintegrasikan informasi dari bukti tersebut (Tantra, 2013). Audit judgment merupakan suatu pertimbangan yang memengaruhi dokumentasi bukti dan keputusan pendapat yang dibuat oleh auditor (Taylor, 2000 dalam Pramono, 2007). Karenanya audit judgment memberikan pengaruh yang signifikan terhadap simpulan akhir dari laporan keuangan, sehingga secara tidak langsung juga akan mempengaruhi tepat atau tidaknya keputusan yang akan diambil oleh pihak luar perusahaan.

Proses judgment tergantung dari asal informasi, karena setiap langkah dalam proses judgment, akan dapat mempengaruhi hasil akhir dari judgment. Judgment dapat berubah tergantung dari informasi yang datang sebagai pertimbangan baru yang dapat digunakan auditor (Tantra, 2013). Kedatangan informasi bukan hanya memengaruhi pilihan yang ditentukan oleh pihak luar peusahaan, tetapi juga memengaruhi cara menentukan pilihan tersebut dibuat. Setiap tahap, di dalam proses audit judgment jika informasi datang terus-menerus, akan muncul pertimbangan baru dan pilihan/ keputusann baru (Praditaningrum, 2012).

Seorang auditor bertugas untuk memberi penilaian tentang keadaan keuangan suatu perusahaan. Dalam pekerjaan audit, judgment merupakan kegiatan yang selalu digunakan auditor dalam setiap proses audit, untuk itu seorang auditor harus terus mengasah terus judgment mereka. Semakin akurat hasil audit judgment yang dibuat oleh seorang auditor maka akan semakin akurat hasil audit yang dihasilkan. Hal itu disebabkan karena judgment yang dibuat auditor merupakan 
Ni Made Krisdhayani dan Ida Bagus Putra Astika. Pengaruh...

sebuah pertimbangan subyektif dari seorang auditor dan sangat tergantung dari persepsi individu mengenai suatu situasi (Lopa, 2016).

Judgment yang dilakukan oleh seorang auditor dalam suatu proses auditnya dipengaruhi oleh banyak faktor, baik bersifat teknis maupun non teknis (Meyer, 2001). Secara teknis, cara pandang seorang auditor dalam menanggapi sebuah informasi, berhubungan dengan tanggungjawab dan risiko audit yang akan dihadapi oleh seorang auditor sehubungan dengan judgment yang dibuatnya. Faktor-faktor yang dapat mempengaruhi persepsi/ pandangan auditor dalam menanggapi serta mengevaluasi sebuah informasi yang didapat antara lain meliputi pengalaman auditor, komitmen organisasi, kompetensi, dan reward saat melakukan pemeriksaan.

Variabel yang digunakan dalam penelitian ini adalah pengalaman audit. Pengalaman merupakan kemampuan yang dimiliki seorang auditor untuk belajar dari adanya kejadian yang terjadi di masa lalu yang berhubungan seluk-beluk audit (Sucipto, 2007). Seorang auditor yang sudah memiliki pengalaman dapat membuat sebuah judgment yang jauh lebih baik didalam tugasnya dibandingkan dengan seorang auditor yang belum memiliki pengalaman. Hal tersebut menunjukkan bahwa semakin banyak pengalaman yang sudah dimiliki oleh seorang auditor, maka judgment yang dihasilkan akan semakin baik dan akurat sehingga dapat menimbulkan kepercayaan dari masyarakat (Martinov dan Pflugrath, 2008).

Selain pengalaman auditor, faktor yang digunakan dalam penelitian ini adalah komitmen organisasi. Robbins dan Timothy (2008) mendefinikan 
komitmen organisasi sebagai suatu keadaan yang dimana seorang karyawan tersebut memihak organisasinya serta tujuan-tujuan dan keinginannya untuk mempertahankan keanggotaan dalam organisasi tersebut. Komitmen anggota organisasi menjadi sebuah hal yang penting bagi organisasi dalam menciptakan perkembangan disuatu organisasi apapun bentuk organisasi yang ada. Komitmen organisasi dapat diartikan sikap kerja seorang auditor yang merupakan sebuah hasil dari proses identifikasi diri dengan tujuan dan nilai-nilai sebuah organisasi yang mempengaruhi keputusan seorang pekerja untuk dapat mempertahankan keanggotaannya di dalam organisasi tersebut. Selain pengalaman, seorang auditor, juga harus memiliki kompetensi.

Seorang auditor dengan kompetensi yang rendah, tidak mampu menemukan penyimpangan yang terjadi dalam perusahaan, sehingga dapat menyebabkan kegagalan dalam proses audit. Maka daripada itu kompetensi juga dapat menentukan keberhasilan dalam pelaksaan audit, tanpa kompetensi auditor internal pelaksanaan audit menjadi kurang berkualitas. Menurut Arens dan Loebbecke (2009:4) auditor harus mempunyai kemampuan memahami kriteria yang digunakan serta mampu menentukan jumlah bahan bukti yang dibutuhkan untuk mendukung kesimpulan yang akan diambilnya. Kompetensi Auditor internal merupakan sebuah cara untuk memanfaatkan pengetahuan, keahlian dan pengalaman. Auditor yang tidak kompeten tidak akan bisa membantu manajemen dalam memecahkan masalah-masalah yang mengandung resiko, sedangkan tugas auditor lebih difokuskan kepada pengawasan dan pengendalian terhadap area-area yang mengandung resiko bukan hanya audit atas kepatuhan saja (Sawyer et. al., 
Ni Made Krisdhayani dan Ida Bagus Putra Astika. Pengaruh...

2005: 17). Auditor dapat dikatakan kompeten atau ahli, apabila dapat melakukan kinerja yang maksimal.

Salah satu faktor pendorong yang dapat mempengaruhi hasil kerja auditor adalah dengan memberikan reward atau penghargaan. Reward adalah sesuatu berupa hadiah baik finansial maupun non finansial yang dapat membuat perasaan senang seorang pegawai, sehingga diharapkan kedepannya pegawai tersebut senantiasa melakukan pekerjaannya dengan lebih baik (Abdurrahman, 2014). Hal ini sesuai dengan teori motivasi yang dikemukakan oleh Robbins dan Judge (2008) yaitu motivasi dapat dimaksud sebagai suatu faktor pendorong yang berada dalam diri manusia yang akan memengaruhi cara bertindak, dengan itu motivasi pada kinerja diri auditor akan berpengaruh terhadap hasil kerjanya. Berarti bahwa pemberian reward atau insentif dari kinerja yang dilakukan oleh seorang auditor mampu memberikan pengaruh untuk memperbaiki kinerja pada audit judgment (Rahayu, 2014). Reward merupakan motivasi kinerja seseorang yang akan diikuti dengan pencapaian kualitas hasil kinerja yang optimal. Pemberian reward merupakan bentuk pengakuan terhadap prestasi kerja, dengan demikian reward dapat dijadikan motivasi pada suatu tingkat perilaku dan prestasi individu. Hal ini juga didukung karena reward dapat dijadikan sebagai penguat berbagai macam perilaku seseorang (Abdurrahman, 2014).

Setiap auditor harus memiliki pengalaman, dan harus tetap mempertahankan kompetensi, komitmen serta memperhatikan reward yang akan diperoleh agar dapat mencegah dan mendeteksi segala bentuk pelanggaran yang terjadi pada perusahaan, sehingga dapat mencapai kualitas audit yang maksimal. 
Berlandaskan pada fenomena dan hasil-hasil penelitian sebelumnya yang telah dipaparkan, maka tujuan penelitian ini adalah untuk mendapatkan bukti empiris pengaruh pengalaman auditor, komitmen organisasi, kompetensi auditor, dan reward pada audit judgment di KAP Provinsi Bali.

Berdasarkan latar belakang dan kajian teoritis diatas maka dapat digambarkan kerangka konseptual pada Gambar 1 seperti berikut:

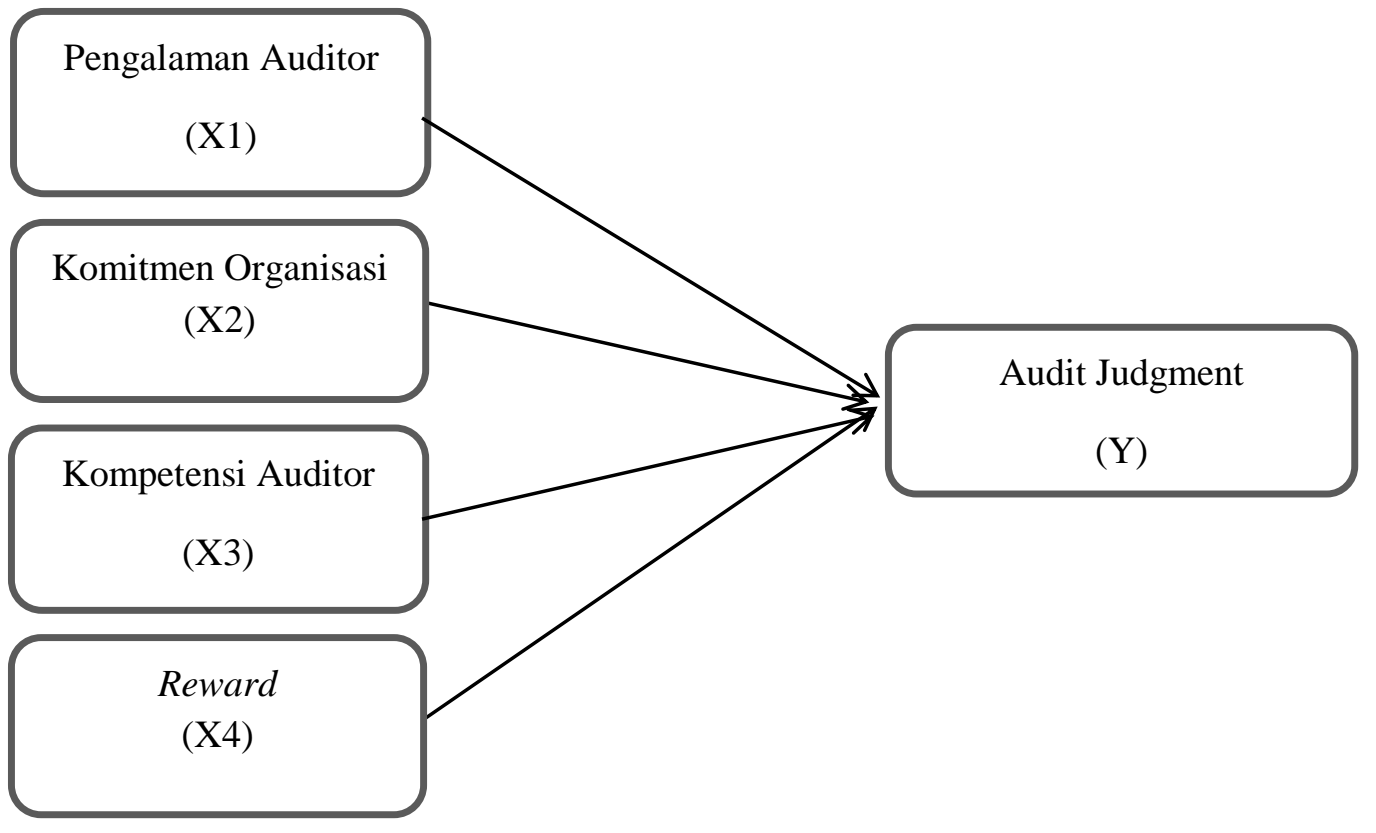

\section{Gambar 1. Kerangka Konseptual}

Berdasarkan latar belakang, tujuan penelitian dan kerangka konseptual yang telah dijelaskan sebelumnya, maka dapat dibuat beberapa hipotesis berikut:

$\mathrm{H}_{1}$ : Pengalaman auditor berpengaruh positif pada audit judgment.

$\mathrm{H}_{2}$ : Komitmen organisasi berpengaruh positif pada audit judgment.

$\mathrm{H}_{3}$ : Kompetensi auditor berpengaruh positif pada audit judgment $\mathrm{H}_{4}$ : Reward berpengaruh positif pada Audit Judgment 
Ni Made Krisdhayani dan Ida Bagus Putra Astika. Pengaruh...

\section{METODE PENELITIAN}

Pendekatan yang digunakan di dalam penelitian ini adalah pendekatan kuantitatif yang berbentuk kausalitas, karena menganalisis hubungan sebab akibat antara variabel pengalaman auditor, komitmen organisasi, kompetensi auditor, dan reward pada audit judgment. Penelitian ini dilakukan pada Kantor Akuntan Publik yang berada di Provinsi Bali dan merupakan anggota Institusi Akuntan Publik Indonesia (IAPI). Lokasi tersebut dipilih untuk memudahkan pengumpulan data karena kantor akuntan publik yang terdaftar dalam Direktori akan mudah diketahui nama beserta alamatnya. Kantor Akuntan Publik yang terdaftar di Direktori telah memperoleh ijin dari Menteri Keuangan Republik Indonesia sebagai wadah dari akuntan publik dalam melaksanakan pekerjaannya.

Variabel independen dalam penelitian ini adalah pengalaman auditor, komitmen organisasi, kompetensi auditor dan reward. Pengalaman audit terdiri dari 5 pernyataan yang diadopsi dari kuisioner penelitian Christanti (2016) yang dimodifikasi agar lebih mencapai tujuan pengukuran dan juga relevan. Variabel komitmen organisasi dalam penelitian ini terdiri dari 7 pernyataan yang diadopsi dari kuisioner penelitian Widyawati (2016) yang dimodifikasi agar lebih mencapai tujuan pengukuran dan juga relevan. Variabel kompetensi auditor dalam penelitian ini terdiri dari 6 pernyataan yang diadopsi dari kuisioner penelitian Windasari dan Juliarsa (2016) yang dimodifikasi agar lebih mencapai tujuan pengukuran dan juga relevan. Variabel reward dalam penelitian ini terdiri dari 6 pernyataan yang diadopsi dari kuisioner penelitian Abdurrahman (2014) yang dimodifikasi agar lebih mencapai tujuan pengukuran dan juga relevan. 
Variabel dependen dalam penelitian ini adalah audit judgment. Audit judgment adalah kebijakan seorang auditor dalam menentukan pendapat/ opini mengenai hasil audit yang mengacu pada pembentukan suatu gagasan, pendapat atau perkiraan tentang suatu objek, peristiwa, status atau jenis peristiwa lain. Indikator-indikator dari variabel audit judgment diambil dari instrumen penelitian yang dikutip dari Puspitasari (2014) dan telah dimodifikasi secara redaksional agar lebih sesuai dengan penelitian ini. Indikator variabel audit judgment dalam penelitian ini antara lain Tingkat materialitas, Tingkat risiko audit, dan Kelangsungan hidup suatu entitas. Variabel audit judgment ini diukur dengan 3 indikator dan 6 item pernyataan.

Populasi yang ada didalam penelitian ini adalah seluruh auditor yang bekerja pada Kantor Akuntan Publik di Bali, yang juga merupakan anggota IAPI tahun 2017 yang berjumlah sebanyak 77 orang auditor. Teknik penentuan sampel yang digunakan dalam penelitian ini adalah metode nonprobability sampling dengan teknik sampel jenuh atau sensus, yaitu teknik penentuan sampel bila semua anggota populasi digunakan sebagai sampel, sehingga jumlah sampel dalam penelitian ini adalah sebanyak 77 orang auditor yang bekerja pada 9 Kantor Akuntan Publik di Provinsi Bali.

Metode pengumpulan data dalam penelitian ini adalah dengan teknik kuesioner. Teknik kuesioner adalah teknik pengumpulan data dengan menggunakan daftar pernyataan yang disebarkan kepada auditor yang bekerja pada KAP di Bali yang terdaftar pada IAPI. Kuesioner yang disebarkan berupa daftar pernyataan dengan bentuk checklist $(\sqrt{ })$ kepada responden mengenai 
Ni Made Krisdhayani dan Ida Bagus Putra Astika. Pengaruh...

variabel penelitian yang diukur menggunakan skala Likert lima poin yaitu poin 1 $=$ sangat tidak setuju, $2=$ tidak setuju, $3=$ netral, $4=$ setuju, dan $5=$ sangat setuju.

Sebelum dilakukannya teknik analisis terhadap data yang telah dikumpulkan terlebih dahulu harus dilakukan pengujian instrumen penelitian terlebih dahulu dalam hal ini adalah pengujian validitas dan reliabilitas. Apabila data sudah dinyatakan valid dan reliabel, maka data layak untuk diuji lebih lanjut.

Teknik analisis data yang digunakan untuk mengetahui atau memperoleh gambaran mengenai pengalaman auditor $\left(\mathrm{X}_{1}\right)$, komitmen organisasi $\left(\mathrm{X}_{2}\right)$, kompetensi auditor $\left(\mathrm{X}_{3}\right)$ dan reward $\left(\mathrm{X}_{4}\right)$ pada Audit Judgment (Y) adalah dengan analisis regresi linier berganda yang dihitung dengan program SPSS for Windows. Model persamaan regresi linear berganda yang digunakan yaitu:

$Y=\alpha+\beta_{1} X_{1}+\beta_{2} X_{2}+\beta_{3} X_{3}+\beta_{4} X_{4}+$ ei.

Keterangan:

Y : Audit judgment

$\alpha \quad$ : Nilai intersep (konstan)

$\beta_{1-} \beta_{4} \quad$ : Koefisien arah regresi

$\mathrm{X}_{1} \quad$ : Pengalaman Auditor

$\mathrm{X}_{2} \quad$ : Komitmen Organisasi

$\mathrm{X}_{3} \quad$ : Kompetensi Auditor

$\mathrm{X}_{4} \quad:$ Reward

ei : error

\section{HASIL DAN PEMBAHASAN}

Penelitian ini dilakukan untuk mengetahui pengaruh pengalaman auditor, komitmen organisasi, kompetensi auditor dan reward pada audit judgment di Kantor Akuntan Publik Provinsi Bali. Pengumpulan data dilakukan melalui penyebaran kuesioner kepada 9 Kantor Akuntan Publik di Provinsi Bali. Penyebaran kuesioner hingga semua kuesioner terjawab dan terkumpul kembali 
pada peneliti menghabiskan waktu 18 hari yaitu mulai tangal 8 Juni sampai 26 Juni 2018. Total kuesioner yang digunakan untuk analisis dalam penelitian ini sebanyak 77 buah.

Karakteristik responden penelitian ini merupakan profil dari 77 responden yang berpartisipasi dalam pengisian kuesioner. Karakteristik responden penelitian meliputi jabatan, umur, jenjang pendidikan terakhir, lama bekerja dan jenis kelamin.

Tabel 1.

Karakteristk Responden Penelitian

\begin{tabular}{|c|c|c|c|}
\hline Karakteristik & Klasifikasi & $\begin{array}{l}\text { Jumlah } \\
\text { (Orang) }\end{array}$ & $\begin{array}{c}\text { Persentase } \\
(\%)\end{array}$ \\
\hline \multirow{5}{*}{ Jabatan } & Auditor Junior & 44 & 57,14 \\
\hline & Auditor Senior & 22 & 28,57 \\
\hline & Manajer & 9 & 11,69 \\
\hline & Partner & 2 & 2,60 \\
\hline & Total & 77 & 100 \\
\hline \multirow{4}{*}{ Umur } & $<26$ tahun & 48 & 62,34 \\
\hline & 26-35 tahun & 17 & 22,08 \\
\hline & 36-45 tahun & 9 & 11,69 \\
\hline & $\geq 46$ tahun & 3 & 3,90 \\
\hline \multirow{6}{*}{$\begin{array}{c}\text { Tingkat } \\
\text { Pendidikan } \\
\text { Terakhir }\end{array}$} & Total & 77 & 100 \\
\hline & D3 & 16 & 20,78 \\
\hline & $\mathrm{S} 1$ & 46 & 59,74 \\
\hline & $\mathrm{S} 2$ & 13 & 16,88 \\
\hline & S3 & 2 & 2,60 \\
\hline & Total & 77 & 100 \\
\hline Karakteristik & Klasifikasi & $\begin{array}{l}\text { Jumlah } \\
\text { (Orang) }\end{array}$ & $\begin{array}{c}\text { Persentase } \\
(\%)\end{array}$ \\
\hline \multirow{4}{*}{ Lama Bekerja } & $<1$ tahun & 24 & 31,17 \\
\hline & 1-3 tahun & 37 & 48,05 \\
\hline & 3-5 tahun & 10 & 12,99 \\
\hline & $>5$ tahun & 6 & 7,79 \\
\hline \multirow{4}{*}{ Jenis Kelamin } & Total & 77 & 100 \\
\hline & Pria & 46 & 59,74 \\
\hline & Perempuan & 31 & 40,26 \\
\hline & Total & 77 & 100 \\
\hline
\end{tabular}

Sumber : Data diolah, 2018

Jabatan digunakan untuk mengetahui kedudukan responden pada Kantor Akuntan Publik. Responden yang menjadi auditor junior sebanyak 44 orang 1702 
Ni Made Krisdhayani dan Ida Bagus Putra Astika. Pengaruh...

(57,14 persen), responden yang menjadi auditor senior sebanyak 22 orang $(28,57$ persen), responden yang menjabat sebagai manajer sebanyak 9 orang $(11,69$ persen), dan responden yang menjadi partner sebanyak 2 orang (2,60 persen).

Umur digunakan untuk mengetahui proporsi rentang usia responden pada Kantor Akuntan Publik. Responden yang berusia dibawah 26 tahun sebanyak 48 orang (62,34 persen), responden yang berusia antara 26 hingga 35 tahun sebanyak 17 orang $(22,08$ persen), responden yang berusia antara 36 hingga 45 tahun sebanyak 9 orang (11,69 persen), dan responden yang lebih dari 46 tahun sebanyak 3 orang $(3,90$ persen$)$.

Tingkat pendidikan digunakan untuk mengetahui proporsi tingkat pendidikan terakhir yang dimiliki responden. Rasponden yang memiliki tingkat pendidikan D3 sebanyak 16 orang (20,78 persen), S1 sebanyak 46 orang $(59,74$ persen), S2 sebanyak 13 orang (16,88 persen) dan S3 sebanyak 2 orang (2,60 persen).

Lamanya bekerja digunakan untuk mengetahui proporsi pengalaman responden dalam mengaudit. Responden yang berpengalaman mengaudit di bawah 1 tahun sebanyak 24 orang (31,17 persen), responden yang berpengalaman mengaudit 1 sampai 3 tahun sebanyak 37 orang (48,05 persen), responden yang berpengalaman mengaudit 3 sampai 5 tahun sebanyak 10 orang (12,99 persen) dan responden yang berpengalaman mengaudit lebih dari 5 tahun sebanyak 6 orang (7,79 persen). Tabel 1 menunjukkan responden yang berjenis kelamin pria sebanyak 46 orang $(59,74$ persen), dan responden yang berjenis kelamin perempuan sebanyak 31 orang (40,26 persen). 
Statistik deskriptif bertujuan untuk memberikan informasi mengenai karakteristik variabel - variabel penelitian yaitu jumlah amata nilai minimum, nilai maksimum, nilai mean, dan standar deviasi.

Tabel 2.

Hasil Statistik Deskriptif Variabel Penelitian

\begin{tabular}{|c|c|c|c|c|c|}
\hline & $\mathbf{N}$ & Minimum & Maximum & Mean & Std. Deviation \\
\hline Audit Judgment & 77 & 14 & 30 & 21.48 & 3.231 \\
\hline Pengalaman Auditor & 77 & 11 & 25 & 17.87 & 2.572 \\
\hline Komitmen Organisasi & 77 & 12 & 35 & 25.48 & 5.328 \\
\hline Kompetensi Auditor & 77 & 14 & 26 & 20.88 & 2.523 \\
\hline Reward & 77 & 10 & 30 & 21.61 & 3.958 \\
\hline Valid N (listwise) & 77 & & & & \\
\hline
\end{tabular}

Sumber : Data diolah, 2018

Berdasarkan hasil uji statistik deskriptif pada Tabel 2 dapat diketahui bahwa total sampel yang digunakan adalah sebanyak 77 orang responden. Variabel audit judgment memiliki nilai minimum sebesar 14 dan nilai maksimum sebesar 30 . Variabel audit judgment yang diukur dengan 6 item pernyataan dengan bantuan skala likert 5 poin memiliki nilai rata-rata sebesar 21,48 berada pada kriteria cukup yaitu pada rentang nilai > 20,4 - 23,60, maka dapat dikatakan bahwa audit judgment pada Kantor Akuntan Publik di Bali sudah cukup baik. Nilai standar deviasi variabel audit judgment sebesar 3,231 lebih rendah dibandingkan dengan nilai rata-rata, yang artinya sebaran data terkait sudah merata.

Variabel pengalaman auditor memiliki nilai minimum sebesar 11 dan nilai maksimum sebesar 25. Variabel pengalaman auditor yang diukur dengan 5 item pernyataan dengan bantuan skala likert 5 poin memiliki nilai rata-rata sebesar 17,87 berada pada kriteria cukup yaitu pada rentang nilai $>16,60-19,40$, maka dapat dikatakan bahwa auditor di Akuntan Publik di Bali sudah memiliki pengalaman yang cukup baik dalam melakukan audit. Nilai standar deviasi 
Ni Made Krisdhayani dan Ida Bagus Putra Astika. Pengaruh...

variabel pengalaman auditor sebesar 2,572 lebih rendah dibandingkan nilai ratarata, yang artinya sebaran data terkait dengan pengalaman auditor sudah merata.

Variabel komitmen organisasi memiliki nilai minimum sebesar 12 dan nilai maksimum sebesar 35. Variabel komitmen organisasi yang diukur dengan 7 item pernyataan dengan bantuan skala likert 5 poin memiliki nilai rata-rata sebesar 25,48 berada pada kriteria cukup yaitu pada rentang nilai $>21,20-25,80$, maka dapat dikatakan bahwa auditor pada Kantor Akuntan Publik di Bali sudah memiliki komitmen organisasi yang cukup tinggi. Nilai standar deviasi variabel komitmen organisasi sebesar 5,328 lebih rendah dibandingkan dengan nilai ratarata, yang artinya sebaran data terkait komitmen organisasi sudah merata.

Variabel kompetensi auditor memiliki nilai minimum sebesar 14 dan nilai maksimum sebesar 26. Variabel kompetensi auditor yang diukur dengan 6 item pernyataan dengan bantuan skala likert 5 poin memiliki nilai rata-rata sebesar 20,88 berada pada kriteria cukup yaitu pada rentang nilai $>18,80-21,20$, maka dapat dikatakan bahwa auditor pada Kantor Akuntan Publik di Bali sudah memiliki kompetensi yang cukup baik dalam melakukan audit. Nilai standar deviasi variabel kompetensi auditor sebesar 2,523 lebih rendah dibandingkan dengan nilai rata-rata, yang artinya sebaran data terkait sudah merata.

Variabel reward memiliki nilai minimum sebesar 10 dan nilai maksimum sebesar 30. Variabel reward yang diukur dengan 6 item pernyataan dengan bantuan skala likert 5 poin memiliki nilai rata-rata sebesar 21,61 berada pada kriteria cukup yaitu pada rentang nilai > 18,80 - 22,00, maka dapat dikatakan bahwa auditor pada Kantor Akuntan Publik di Bali sudah memperoleh reward 
yang cukup baik. Nilai standar deviasi variabel reward sebesar 3,958 lebih rendah dibandingkan nilai rata-rata, yang artinya sebaran data terkait sudah merata.

Sebelum data dianalisis lebih lanjut, maka dilakukan uji instrumen penelitian dengan menggunakan uji validasi dan uji reliabiltas seperti Tabel 3.

Tabel 3.

Hasil Uji Validitas

\begin{tabular}{|c|c|c|c|c|c|c|c|c|c|c|}
\hline \multicolumn{2}{|c|}{$\begin{array}{c}\text { Kinerja } \\
\text { Karyawan } \\
\text { (Y) }\end{array}$} & \multicolumn{2}{|c|}{$\begin{array}{c}\text { Pengalaman } \\
\text { Auditor } \\
\left(\mathbf{X}_{1}\right)\end{array}$} & \multicolumn{2}{|c|}{$\begin{array}{c}\text { Komitmen } \\
\text { Organisasi } \\
\left(\mathrm{X}_{2}\right)\end{array}$} & \multicolumn{2}{|c|}{$\begin{array}{c}\text { Kompetensi } \\
\text { Auditor } \\
\left(\mathbf{X}_{3}\right)\end{array}$} & \multicolumn{2}{|c|}{$\begin{array}{c}\text { Reward } \\
\left(\mathrm{X}_{4}\right)\end{array}$} & \multirow{2}{*}{$\begin{array}{c}\text { Keterangan } \\
\text { Valid }\end{array}$} \\
\hline$Y_{1}$ & 0,676 & $\mathrm{X}_{1.1}$ & 0,585 & $\mathrm{X}_{2.1}$ & 0,765 & $\mathrm{X}_{3.1}$ & 0,446 & $\mathrm{X}_{4.1}$ & 0,876 & \\
\hline$Y_{2}$ & 0,561 & $\mathrm{X}_{.1 .2}$ & 0,427 & $\mathrm{X}_{2.2}$ & 0,791 & $\mathrm{X}_{3.2}$ & 0,575 & $\mathrm{X}_{4.2}$ & 0,750 & Valid \\
\hline$Y_{3}$ & 0,636 & $\mathrm{X}_{.1 .3}$ & 0,482 & $\mathrm{X}_{2.3}$ & 0,844 & $\mathrm{X}_{3.3}$ & 0,557 & $\mathrm{X}_{4.4}$ & 0,703 & Valid \\
\hline$Y_{4}$ & 0,719 & $\mathrm{X}_{.1 .4}$ & 0,734 & $\mathrm{X}_{2.4}$ & 0,644 & $X_{3.4}$ & 0,472 & $X_{4.4}$ & 0,761 & Valid \\
\hline $\mathrm{Y}_{5}$ & 0,785 & $X_{.1 .5}$ & 0,645 & $\mathrm{X}_{2.5}$ & 0,859 & $\mathrm{X}_{3.5}$ & 0,536 & $\mathrm{X}_{4.5}$ & 0,672 & Valid \\
\hline \multirow[t]{2}{*}{$\mathrm{Y}_{6}$} & 0,604 & & & $\mathrm{X}_{2.6}$ & 0,743 & $X_{3.6}$ & 0,515 & $X_{4.6}$ & 0,672 & Valid \\
\hline & & & & $\mathrm{X}_{2.7}$ & 0,519 & $\mathrm{X}_{3.1}$ & 0,446 & $\mathrm{X}_{4.1}$ & 0,876 & Valid \\
\hline
\end{tabular}

Hasil uji validitas yang menunjukkan bahwa seluruh variabel memiliki nilai koefisien korelasi dengan skor total seluruh item pernyataan lebih besar dari 0,30. Hal ini menunjukkan bahwa butir-butir pernyataan dalam instrument penelitian tersebut valid. Setelah dilakukan uji validitas, langkah selanjutnya adalah melakukan uji reliablitias data yang dapat dilihat pada Tabel 4.

Tabel 4.

Hasil Uji Reliabilitas

\begin{tabular}{clcc}
\hline No. & \multicolumn{1}{c}{ Variabel } & Cronbach's Alpha & Keterangan \\
\hline $\mathbf{1}$ & Audit Judgment $(\mathrm{Y})$ & 0,764 & Reliabel \\
$\mathbf{2}$ & Pengalaman Auditor $\left(\mathrm{X}_{1}\right)$ & 0,724 & Reliabel \\
$\mathbf{3}$ & Komitmen Organisasi $\left(\mathrm{X}_{2}\right)$ & 0,782 & Reliabel \\
$\mathbf{4}$ & Kompetensi Auditor $\left(\mathrm{X}_{3}\right)$ & 0,690 & Reliabel \\
$\mathbf{5}$ & Reward $\left(\mathrm{X}_{4}\right)$ & 0,786 & Reliabel \\
\hline \multicolumn{2}{l}{ Sumber } & Data diolah, 2018
\end{tabular}

Hasil uji reliabilitas menunjukkan bahwa seluruh instrumen penelitian memiliki koefisien Cronbach's Alpha lebih dari 0,60. Hal ini dapat dikatakan bahwa semua instrumen reliabel sehingga dapat digunakan untuk melakukan 
Ni Made Krisdhayani dan Ida Bagus Putra Astika. Pengaruh...

penelitian. Hasil uji asumsi klasik yang dilakukan dalam penelitian ini adalah uji normalitas, uji multikolinearitas dan uji heteroskedastisitas.

Tabel 5.

Hasil Uji Normalitas

\begin{tabular}{llr}
\hline & One-Sample Kolmogorov-Smirnov Test & \\
\hline & & $\begin{array}{c}\text { Unstandardized } \\
\text { Residual }\end{array}$ \\
\hline $\mathrm{N}$ & & 77 \\
Normal Parameters ${ }^{\mathrm{a}, \mathrm{b}}$ & Mean & .0000000 \\
& Std. Deviation & .44080591 \\
Most Extreme Differences & Absolute & .061 \\
& Positive & .061 \\
Kolmogorov-Smirnov Z & Negative & -.035 \\
\hline
\end{tabular}

Sumber : Data diolah, 2018

Tabel 5 menunjukkan bahwa nilai Kolmogorov Sminarnov (K-S) sebesar 0,343, sedangkan nilai Asymp. Sig. (2-tailed) sebesar 1,000. Hasil tersebut mengindikasikan bahwa model persamaan regresi tersebut berdistribusi normal karena nilai Asymp. Sig. (2-tailed) 1,000 lebih besar dari nilai alpha 0,05.

Tabel 6.

Hasil Uji Multikoleniaritas

\begin{tabular}{lccc}
\hline \multicolumn{1}{c}{ Variabel } & Tolerance & VIF & Keterangan \\
\hline Pengalaman Auditor $\left(\mathrm{X}_{1}\right)$ & 0,573 & 1,746 & Bebas multikol \\
Komitmen Organisasi $\left(\mathrm{X}_{2}\right)$ & 0,659 & 1,519 & Bebas multikol \\
Kompetensi Auditor $\left(\mathrm{X}_{3}\right)$ & 0,618 & 1,619 & Bebas multikol \\
Reward $\left(\mathrm{X}_{4}\right)$ & 0,710 & 1,409 & Bebas multikol \\
\hline
\end{tabular}

Sumber : Data diolah, 2018

Berdasarkan Tabel 6 dapat dilihat bahwa nilai tolerance dan VIF dari seluruh variable tersebut menunjukkan bahwa nilai tolerance untuk setiap variabel lebih besar dari $10 \%$ dan nilai VIF lebih kecil dari 10 yang berarti model persamaan regresi bebas dari multikolinearitas. 
Tabel 7.

Hasil Uji Heteroskedastisitas

\begin{tabular}{clcl}
\hline No & \multicolumn{1}{c}{ Variabel Bebas } & Signifikansi & Keterangan \\
\hline 1 & Pengalaman Auditor $\left(\mathrm{X}_{1}\right)$ & 0,901 & Bebas heteros \\
2 & Komitmen Organisasi $\left(\mathrm{X}_{2}\right)$ & 0,434 & Bebas heteros \\
3 & Kompetensi Auditor $\left(\mathrm{X}_{3}\right)$ & 0,935 & Bebas heteros \\
4 & Reward $\left(\mathrm{X}_{4}\right)$ & 0,956 & Bebas heteros \\
\hline
\end{tabular}

Sumber : Data diolah, 2018

Pada Tabel 7 dapat dilihat bahwa nilai signifikansi dari variabel pengalaman auditor sebesar 0,901, komitmen organisasi sebesar 0,434, kompetensi auditor sebesar 0,935, dan variabel reward sebesar 0,956. Nilai tersebut lebih besar dari 0,05 yang berarti tidak terdapat pengaruh antara variabel bebas terhadap absolute residual. Dengan demikian, model yang dibuat tidak mengandung gejala heteroskedastisitas.

Setelah semua asumsi klasik terpenuhi, maka selanjutnya memaparkan hasil analisis regresi linier berganda, yang ditunjukan pada Tabel 8 berikut:

Tabel 8.

Hasil Analisis Regresi Linier Berganda

\begin{tabular}{|c|c|c|c|c|c|c|}
\hline \multirow{2}{*}{\multicolumn{2}{|c|}{ Model }} & \multicolumn{2}{|c|}{$\begin{array}{l}\text { Unstandardized } \\
\text { Coefficients }\end{array}$} & \multirow{2}{*}{$\begin{array}{c}\text { Standardized } \\
\text { Coefficients } \\
\text { Beta }\end{array}$} & \multirow[b]{2}{*}{$\mathbf{t}$} & \multirow[b]{2}{*}{ Sig. } \\
\hline & & $\mathrm{B}$ & Std. Error & & & \\
\hline \multirow[t]{5}{*}{1} & (Constant) & -.449 & 1.954 & & -.230 & .819 \\
\hline & Pengalaman Auditor & .385 & .113 & .306 & 3.415 & .001 \\
\hline & Komitmen Organisasi & .104 & .051 & .172 & 2.055 & .044 \\
\hline & Kompetensi Auditor & .346 & .111 & .270 & 3.126 & .003 \\
\hline & Reward & .239 & .066 & .293 & 3.639 & .001 \\
\hline
\end{tabular}

Sumber : Data diolah, 2018

Berdasarkan hasil analisis regresi linier berganda seperti yang disajikan pada Tabel 8, maka dapat dibuat persamaan regresi sebagai berikut:

$$
Y=-0,449+0,385 X_{1}+0,104 X_{2}+0,346 X_{3}+0,239 X_{4}
$$

Persamaan regresi pada Tabel 8 menunjukkan nilai konstanta (a) sebesar 0,449, berarti bahwa nilai variabel audit judgment $(\mathrm{Y})$, pengalaman auditor $\left(\mathrm{X}_{1}\right)$, 
Ni Made Krisdhayani dan Ida Bagus Putra Astika. Pengaruh...

komitmen organisasi $\left(\mathrm{X}_{2}\right)$, kompetensi auditor $\left(\mathrm{X}_{3}\right)$, dan rewards $\left(\mathrm{X}_{4}\right)$ sama dengan nol, maka tidak terdapat nilai kualitas audit. Hasil juga menunjukkan bahwa seluruh variabel bebas memiliki nilai signifikansi kurang dari 0,05 dengan nilai koefisien regresi positif. Hal tersebut berarti bahwa terdapat pengaruh yang positif dan signifikan dari pengalaman auditor $\left(\mathrm{X}_{1}\right)$, komitmen organisasi $\left(\mathrm{X}_{2}\right)$, kompetensi auditor $\left(\mathrm{X}_{3}\right)$, dan rewards $\left(\mathrm{X}_{4}\right)$ terhadap variabel audit judgment $(\mathrm{Y})$. Hal ini mengindikasikan bahwa pengalaman auditor dan komitmen organisasi yang tinggi dan didukung oleh kompetensi yang baik serta pemberian reward yang baik, maka dapat meningkatkan audit judgment.

Hasil analisis regresi menunjukkan bahwa pengalaman auditor berpengaruh positif pada audit judgment $\left(\mathrm{H}_{1}\right.$ diterima). Hal ini berarti bahwa semakin banyak pengalaman auditor dalam melakukan audit, maka akan semakin meningkatkan kemampuan auditor untuk memprediksi dan mendeteksi kecurangan yang terjadi dalam pelaporan keuangan suatu perusahaan yang diauditnya, sehingga dapat menghasilkan sebuah judgment yang lebih baik. Begitu juga sebaliknya semakin sedikit pengalaman auditor dalam melakukan audit, maka tidak akan mampu meningkatkan kemampuan auditor untuk memprediksi dan mendeteksi kecurangan yang terjadi dalam pelaporan keuangan suatu perusahaan yang diauditnya, sehingga tidak dapat menghasilkan sebuah judgment yang baik.

Seorang auditor harus memiliki motivasi yang tinggi untuk mencapai tujuan audit dan tujuan organisasi dengan baik dan tepat. Auditor yang memiliki motivasi kuat akan terus berusaha menambah pengalaman untuk mendukung 
kinerjanya. Pengalaman auditor akan membuat seorang auditor semakin terlatih dalam melakukan tugas auditnya. Hasil penelitian ini didukung oleh hasil penelitian yang dilakukan Raiyani (2014) dan Shelton (1999) yang mendapatkan hasil bahwa pengalaman auditor berpengaruh positif dan signifikan pada audit judgment. Semakin tinggi tingkat pengalaman auditor yang didapat selama auditor bekerja dapat menghasilkan audit judgment yang semakin baik dan tepat.

Hasil analisis regresi menunjukkan bahwa komitmen organisasi berpengaruh positif pada audit judgment $\left(\mathrm{H}_{2}\right.$ diterima). Hal ini berarti bahwa semakin tinggi komitmen yang dimiliki seorang auditor maka akan semakin meningkatkan fokus auditor dalam melakukan tugas auditnya, sehingga mampu menghasilkan sebuah judgment yang lebih baik. Begitu juga sebaliknya semakin rendah komitmen yang dimiliki seorang auditor maka akan semakin mengurangi fokus auditor dalam melakukan tugas auditnya, sehingga tidak akan mampu menghasilkan sebuah judgment yang baik.

Auditor harus dapat memiliki sebuah penetapan tujuan. Keinginan auditor untuk mencapai sebuah tujuan merupakan sumber motivasi kerja yang utama. Seorang auditor dengan tujuan yang lebih spesifik serta menantang akan dapat menghasilkan kinerja yang lebih tinggi dibandingkan dengan tujuan yang tidak jelas. Hal ini diperlukan berkaitan dengan komitmen organisasi dimana bila auditor memiliki nilai tersendiri yang diukur dari identifikasi diri dengan adanya penetapan tujuan serta nilai-nilai organisasi yang mempengaruhi keputusan seorang karyawan untuk dapat mempertahankan keanggotaan didalam suatu organisasi, maka auditor harus tetap fokus dengan apa yang dikerjakan agar tujuan 
Ni Made Krisdhayani dan Ida Bagus Putra Astika. Pengaruh...

awal yang telah disepakati berjalan sesuai dengan yang direncanakan.

Hasil penelitian ini sesuai dengan hasil penelitian Riswan (2012) yang menemukan hasil bahwa terdapat pengaruh positif dan signifikan antara komitmen organisasi dengan kualitas audit, dan untuk dapat memenuhi kualitas audit yang baik maka auditor dalam menjalankan profesi harus mempunyai komitmen pada organisasi, berpedoman kepada kode etik akuntan, standar profesi dan standar akuntansi keuangan lainnya. Karena keberhasilan dan kinerja seorang karyawan didalam suatu bidang pekerjaan banyak ditentukan dengan salah satu faktor yaitu komitmennya pada bidang pekerjaan yang ditekuninya. Komitmen dapat diartikan sebagai tingkat loyalitas seorang karyawan pada profesi yang ditekuninya atas dasar persepsi oleh individu tersebut. Maka dari itu semakin kuat komitmen yang ada di suatu organisasi tersebut semakin baik juga hasil audit dan judgment yang dihasilkan masing-masing individu.

Hasil analisis regresi menunjukkan bahwa kompetensi auditor berpengaruh positif pada audit judgment $\left(\mathrm{H}_{3}\right.$ diterima). Hal ini berarti bahwa semakin baik kompetensi yang dimiliki seorang auditor maka akan semakin meningkatkan kualitas audit, sehingga hasil audit dan judgment yang dihasilkan menjadi lebih objektif, cermat dan seksama. Begitu juga sebaliknya semakin buruk kompetensi yang dimiliki seorang auditor maka tidak akan mampu meningkatkan kualitas audit yang akan menghasilkan judgment menjadi lebih objektif, cermat dan seksama.

Pengaruh kompetensi auditor pada audit judgment ini sesuai dengan teori pengambilan keputusan (behavioral decision theory). Teori pengambilan 
keputusan menyatakan bahwa apabila seseorang yang mempunyai keterbatasan ilmu dan pengetahuan bertindak hanya berdasarkan pemikiran pribadi pada suatu situasi yang sedang dihadapi. Masing-masing individu mempunyai tingkatan pengetahuan yang berbeda dan pada kondisi tersebut akan mempengaruhi cara pembuatan suatu keputusan dimana hal itu tidak dapat dilepaskan dari berbagai konteks sosial yang ada berupa tekanan-tekanan politik, sosial, dan ekonomi. Dalam pengambilan keputusan, pembuat keputusan tidak lagi menggunakan pikiran yang rasional jika dia merasa bahwa keputusan yang dia ambil sangat erat kaitannya dengan kepentingan-kepentingan pribadinya (Kristanti, 2008). Oleh karena itu dapat disimpulkan bahwa semakin baik kompetensi yang dimiliki oleh auditor, maka pengambilan keputusan auditor akan semakin tepat dalam melakukan audit.

Hasil penelitian ini sesuai dengan hasil penelitian Pandoyo (2016) dan Halim et al. (2014) yang memperoleh hasil bahwa kompetensi auditor berpengaruh positif pada audit judgment. Artinya semakin tinggi kompetensi yang dimiliki auditor, maka kualitas audit akan semakin tinggi, sehingga hasil audit dan judgment yang dihasilkan akan semakin baik. Hasil penelitian ini juga didukung oleh temuan Rosalina (2013), Nelli (2014), Syamsuddin et al. (2014), Nugraheni dan Suzan (2015) dan Wahyuni (2013) yang menemukan hasil bahwa kompetensi berpengaruh positif dan signifikan pada audit judgment.

Hasil analisis regresi menunjukkan bahwa reward berpengaruh positif pada audit judgment $\left(\mathrm{H}_{4}\right.$ diterima). Hal ini berarti bahwa semakin tinggi reward yang diperoleh seorang auditor maka akan semakin meningkatkan semangat dan 
Ni Made Krisdhayani dan Ida Bagus Putra Astika. Pengaruh...

kinerja auditor, sehingga mampu menghasilkan suatu keputusan atau judgment yang lebih baik dan akurat. Begitu juga sebaliknya semakin rendah reward yang diperoleh seorang auditor maka tidak akan mampu meningkatkan semangat dan kinerja auditor, sehingga tidak mampu menghasilkan suatu keputusan atau judgment yang baik dan akurat.

Reward dapat diartikan sebagai ganjaran, hadiah, dan upah. Pengaruh reward pada audit judgment ini sesuai dengan teori motivasi. Motivasi dapat dimaksud sebagai suatu faktor pendorong yang berada dalam diri manusia yang akan memengaruhi cara bertindak, dengan itu motivasi pada kinerja diri auditor akan berpengaruh pada hasil kerjanya (Rahayu, 2014). Hal ini berarti bahwa reward dari kinerja yang dilakukan oleh seorang auditor mampu memberikan pengaruh untuk memperbaiki kinerja pada audit judgment.

Hasil penelitian ini sesuai dengan hasil penelitian Heriansyah (2016) dan Ardini (2010) yang memperoleh hasil bahwa reward berpengaruh positif pada audit judgment. Artinya kompensasi dari organisasi berupa penghargaan sesuai profesinya, akan meningkatkan kualitas audit karena mereka merasa bahwa organisasi telah memperhatikan kebutuhan dan pengharapan kerja mereka. Dalam hubungannya dengan audit judgment, reward yang konsisten diberikan akan dapat meningkatkan kualitas individu yang nantinya akan mempengaruhi judgment yang dapat dihasilkan. Maka dari itu dengan adanya reward tersebut nantinya akan dapat menghasilkan suatu keputusan atau judgment yang lebih baik dan akurat.

Implikasi teoritis dalam penelitian ini dapat memberikan kontribusi mengenai pengaruh pengalaman auditor, komitmen organisasi, kompetensi auditor 
dan reward pada audit judgment di Kantor Akuntan Publik Provinsi Bali. Hasil uji hipotesis dalam penelitian ini ditemukan bahwa seluruh variabel bebas yang terdiri dari pengalaman auditor $\left(\mathrm{X}_{1}\right)$, komitmen organisasi $\left(\mathrm{X}_{2}\right)$, kompetensi auditor $\left(\mathrm{X}_{3}\right)$, dan reward $\left(\mathrm{X}_{4}\right)$, secara statistik berpengaruh positif pada audit judgment, sehingga variabel tersebut dapat dipertahankan sebagai variabel bebas untuk penelitian selanjutnya.

Implikasi praktis dalam penelitian ini yaitu memberikan implikasi bagi Kantor Akuntan Publik Provinsi Bali sebagai bahan pertimbangan dan evaluasi mengenai audit judgment serta faktor-faktor yang memengaruhinya. Auditor di Kantor Akuntan Publik Provinsi Bali dalam melakukan audit sebaiknya dapat melihat dan mempertimbangkan faktor pengalaman auditor, komitmen organisasi, kompetensi auditor dan reward, karena hal tersebut dapat mempengaruhi audit judgment seorang auditor di Kantor Akuntan Publik Provinsi Bali.

\section{SIMPULAN}

Simpulan yang dapat diberikan berdasarkan hasil penelitian yang dilakukan yaitu pengalaman auditor berpengaruh positif pada audit judgment, komitmen organisasi berpengaruh positif pada audit judgment, kompetensi auditor berpengaruh positif pada audit judgment, dan reward berpengaruh positif pada audit judgment.

Berdasarkan hasil penelitian, analisis, serta kesimpulan di atas, maka saran yang dapat diberikan yaitu Kantor Akuntan Publik Provinsi Bali sebaiknya selalu melakukan pengembangan kompetensi dan pengalaman auditornya, tidak hanya mempertimbangkan faktor-faktor teknis saja tapi juga mempertimbangkan faktor- 
Ni Made Krisdhayani dan Ida Bagus Putra Astika. Pengaruh...

faktor non teknis, karena kompetensi dan pengalaman seorang auditor sangat mempengaruhi audit judgment yang dihasilkan.

Saran bagi peneliti selanjutnya hendaknya memperbanyak sampel yang menjadi responden. Peneliti selanjutnya dapat mengambil sampel auditor tidak hanya yang ada di Bali, tapi juga di daerah-daerah lain atau mungkin sebagian besar auditor pemerintah. Dengan demikian hasilnya diharapkan dapat lebih mewakili populasinya atau dapat digeneralisasi lebih baik. Penelitian selanjutnya juga dapat menambah variabel independen yang mempengaruhi audit judgment agar dapat mempengaruhi dan memperkuat variabel dependen, seperti variabel self efficacy, kompleksitas audit, tekanan ketaatan maupun variabel lainnya.

\section{REFERENSI}

Abdurrahman. (2014). Pengaruh Faktor Kompetensi, Stres Kerja dan Sistem Reward Terhadap Kinerja Auditor Eksternal Pemerintah (Studi Empiris pada BPK RI Perwakilan Provinsi Sulawesi Selatan). Skripsi. Makassar: Universitas Hasanuddin.

Anne Collins McLaughlin. (2013). Effects of Knowledge and Internal Locus of Control in Groups of Health Care Workers Judging Likelihood of Pathogen Transfer. Human Factors and Ergonomics Society. 55(4), 803-814.

Ardini, L. (2010). Pengaruh Kompetensi, Independensi, Akuntabilitas, dan Motivasi terhadap Kualitas Audit. STIESIA. Surabaya.

Christanti, Made Puspita. (2016). Pengaruh Pengalaman Auditor, Locus of Control dan Pengetahuan Mendeteksi Kekeliruan Pada Audit Judgment (Studi Empiris Pada Kantor Akuntan Publik di Bali). Skripsi. Fakultas Ekonomi dan Bisnis Universitas Udayana. Denpasar.

Fitriani, Seni dan Daljono. (2012). Pengaruh Tekanan Ketaataan Kompleksitas Tugas, Pengetahuan dan Persepsi Etis Terhadap Audit Judgment. Diponegoro Journal of Accounting, 1(1), Tahun 2012.

Gibbin, M. (1984). Propositions About The Psychology of Proessional Judgment in Public Accounting. Journal of Accounting Research, 103-125. 
Halim, Abdul. Sutrisno T, Rosidi and M. Achsin. (2014). Effect of Competence and Auditor Independence on Audit Quality with Audit Time Budget and Professional Commitment as a Moderation Variable. International Journal of Business and Management Invention, 3(6). 64-74.

Hogarth. R. M., dan H.J. Einhorn. (1992). Order Effects in Belief Updatang: The Belief Adjustment Mode, Cognitive Psychology. 2(4), 1-55.

Idris, Fitriani Seni. (2012). Pengaruh Tekanan Ketaatan, Kompleksitas Tugas, Pengetahuan dan Persepsi Etis Terhadap Audit Judgement. Skripsi. Fakultas Ekonomika dan Bisnis Universitas Diponegoro. Semarang.

Ikatan Akuntan Publik Indonesia (IAPI). www.iapi.or.id. Daftar Nama KAP di Provinsi Bali. Diakses tanggal 28 Februari 2018

Irawati, ST. Nur. (2011). Pengaruh Kompetensi dan Independensi Auditor Terhadap Kualitas Audit Pada Kantor Akuntan Publik di Makassar. Skripsi. Fakultas Ekonomi Universitas Hasanuddin Makassar.

Iyer, Venkataraman M. and Dasaratha V. Rama. (2004). Clients' Expectations on Audit Judgments: A Note. Behavioral Research In Accounting. 4(16), 63-74.

Jamilah, Siti, Zaenal Fanani, dan Grahita Chandrarin. (2007). Pengaruh Gender, Tekanan Ketaatan, dan Kompleksitas Tugas Terhadap Audit Judgement. Simposium Nasional Akuntansi 10. Unhas Makassar.

Knoers dan Haditono. (1999). Psikologi Perkembangan: Pengantar Dalam Berbagai Bagian. Cetakan ke-12, Gajah Mada University Press Yogyakarta.

Kristanti, Meifilia. (2008). Analisis Faktor-faktor yang Mempengaruhi Ekspektasi Klien dalam Audit Judgment (Studi Empiris Pada Perusahaan Manufaktur Berskala Besar di Semarang). Skripsi. Fakultas Ekonomi Universitas Katolik Soegijapranata, Sumarang.

Locke, E.A. (1968). Toward a Theory of Task Motivation and Incentives. Organizational Behavior and Human Performance, 3(16).

Lopa, Nur Azizah Arief. (2014). "Pengaruh Tekanan Ketaatan, Kompleksitas Tugas dan Pengalaman Kerja Auditor Pada Pertimbangan Audit”. Skripsi Universitas Hasanuddin, Makassar.

Malik, Abdul. (2017). Ernst dan Young Indonesia Didenda di AS, Ini Tanggapan Indosat. https://m.tempo.co/read/news/2017/02/11/087845617/ernst-young -indonesia-didenda-di-as-ini-tanggapan-indosat. Diunduh tanggal 20 Agustus 2017. 
Ni Made Krisdhayani dan Ida Bagus Putra Astika. Pengaruh...

Mayasari, Dian. (2011). "Pengaruh Profesionalisme, Independensi, Kompetensi, Etika Profesi dan Pengetahuan Auditor dalam Mendeteksi Kekeliruan Terhadap Ketepatan Pemberian Opini Audit oleh Auditor (Studi Empiris Pada Kantor Akuntan Publik di Jakarta”. Skripsi S1 Universitas Islam Negeri Syarif Hidayatullah. Jakarta.

Mc. Clelland, David C. (1961). The Achieving Society. New York:D. Van Nostrand Company, Inc.

Meyer, M. dan J. T. Rigsby. (2001). Descriptive Analysis of The Content and Contribution of Behavioral Research In Accounting 1989-1998. Accounting Journal.

Mulyadi. (2010). Auditing. Buku 1.Edisi ke-6.Cetakan ke-1. Jakarta: Salemba Empat.

Nelli, Novyarni. (2014). Influence Of Internal Auditor Competence And Independence On The Quality Of Financial Reporting By Municipal/Provincial Government. International Journal of Economics, Commerce and Management. 2(10), Oct 2014.

Nugraheni Yunita dan Leny Suzan. (2015). Pengaruh Kompetensi, Independensi Dan Audit Fee Terhadap Kualitas Audit Bandung. Jurnal Prodi S1 Akuntansi. Fakultas Ekonomi dan Bisnis. Universitas Telkom.

Pandoyo. (2016). The Effect Of Auditor Competence, Independence, Audit Experience, Organizational Culture And Leadership Against Auditor Professionalism And Its Implication On Audit Quality. International Journal of Advanced Research. 4(5), 1632-1646.

Praditaningrum, Suci Anugrah. (2012). Analisis Faktor-Faktor Yang Berpengaruh Terhadap Audit Judgement. Skripsi Fakultas Ekonomika dan Bisnis Universitas Diponegoro. Semarang.

Pramono, Ristyo. (2007). Pengaruh Dimensi Profesional Auditor Terhadap Pertimbangan Tingkat Materialitas Dalam Proses Pengauditan Laporan Keuangan. Skripsi S1 Universitas Negeri Semarang.

Puspitasari, Ayu Rahmi. (2011). Analisis Pengaruh Gender, Tekanan Ketaatan, Kompleksitas Tugas dan Pengalaman Terhadap Kinerja Auditor Dalam Pembuatan Audit Judgement. Fakultas Ekonomi Universitas Diponegoro. Semarang.

Pujianto, Wahyu Eko. (2013). Pengaruh Sistem Pengukuran Kinerja dan Sistem Reward Terhadap Total Quality Management dan Kinerja Managerial pada Mic Transformer Surabaya. Jurnal. 1(2), 187-202. 
Puput Raiyani dan I. D. G. Dharma Suputra. (2014). Pengaruh Kompetensi, Kompleksitas Tugas, dan Locus of Control terhadap Audit Judgment. Ejurnal Akuntansi Universitas Udayana, Bali.

Puspitasari, Rizsqi. (2014). Pengaruh Profesionalisme, Kompleksitas Tugas, dan Pengalaman Auditor terhadap Auditor Judgment pada Kantor Akuntan Publik. Skripsi Universitas Diponegoro, Semarang.

Rahayu, Fitriana. (2014). Pengaruh Kompleksitas Tugas, Tekanan Ketaatan, Tingkat Senioritas Auditor, Keahlian Auditor, Dan Hubungan Dengan Klien Terhadap Audit Judgement. Fakultas Ekonomi Universitas Riau.

Robbins, Stephen P. dan Judge, Timothy A. (2008). Perilaku Organisasi, Jakarta: Salemba Empat.

Robbins, Stephen P dan Timothy A. Judge. (2015). Perilaku Organisasi : Organizational Behaviour. Edisi 16. Jakarta : Salemba Empat.

Rosalina, Amalia Dewi. (2013). Pengaruh Kompetensi dan Independensi Auditor terhadap Kualitas Audit (Studi Empiris Pada Kantor Akuntan Publik di Bandung). Skripsi. Universitas Widyatama: tidak dipublikasikan

Sanjiwani, D.M.P dan Wisadha, I.G.S. (2016). Pengaruh Locus of Control, Gaya Kepemimpinan Dan Komitmen Organisasi Pada Kinerja Auditor Kantor Akuntan Publik. E-jurnal Akuntansi Universitas Udayana, 14(2), 920-947

Sucipto, Andre. (2007). Analisis Pengaruh Pengetahuan dan Pengalaman terhadap Kemampuan Akuntan Pemeriksa dalam Mendeteksi Kekeliruan pada KAP di Surabaya. Thesis. Universitas Petra Surabaya.

Sugiyono, (2014). Metode Penelitian Bisnis (pendekatan kuantitati, kualitatif, dan $R \& D)$. Penerbit Alfabeta.

Syamsuddin. (2014). The Influences Of Ethics, Independence, And Competence On The Quality Of An Audit Through The Influence Of Profesional Skepticism In Bpk Of South Sulawesi, Central Sulawesi And West Sulawesi. Journal of Research in Business and Management, 2(7), 08-14.

Tantra, Victorio. (2013). Analisis Pengaruh Gender, Tekanan Ketaatan, Kompleksitas Tugas, Pengalaman Audit, Dan Keahlian Audit Terhadap Audit Judgment. Skripsi Fakultas Bisnis Universitas Katolik Widya Mandala Surabaya.

Wahyuni, Rizki. (2013). Pengaruh Independensi, Kompetensi, Profesionalisme, Dan Sensitivitas Etika Profesi Terhadap Kualitas Audit (Studi Kasus Pada 
Ni Made Krisdhayani dan Ida Bagus Putra Astika. Pengaruh...

Bpk Ri Perwakilan Provinsi Sulawesi Selatan. Skripsi. Fakultas Ekonomi dan Bisnis. Universitas Hasanuddin.

Wijono, Sutarto. (2010). Psikologi Industri dan Organisasi. Jakarta: Kencana.

Windasari, M. Yunita., dan Gede Juliarsa. (2016). Pengaruh Kompetensi, Independensi, dan Profesionalisme Auditor Internal Dalam Mencegah Kecurangan Pada Bpr Di Kabupaten Badung. E-Jurnal Akuntansi Universitas Udayana, 17(3), 1924-1952 